\title{
IMPACT OF AMPK ACTIVATOR METFORMIN ON SPERM QUALITY
}

\author{
Nguyen Thi Mong Diep ${ }^{1, \bowtie}$, Elisabeth Blesbois ${ }^{2}$ \\ ${ }^{1}$ Quy Nhon University, Viet Nam \\ ${ }^{2}$ National Institute of Agricultural Research, Physiology of Reproduction and Behaviors, 37380 Nouzilly, \\ France
}

$\bowtie$ To whom correspondence should be addressed. E-mail: diepdhqn@ymail.com

Received: 19.7.2017

Accepted: 29.12.2017

\section{SUMMARY}

\begin{abstract}
Semen cryopreservation allows crucial management of animal genetic diversity. However, the freezethaw process causes biochemical and physical alterations, impairing sperm energy-dependent functions. Currently, many chemicals are added to the media to enhance frozen-thawed sperm quality during artificial insemination. The aims of this study was to determine the effects of Metformin (Metf) on fresh chicken sperm motility and ability to perform acrosome reaction, and to evaluate Metf's effects on the functions of cryopreserved sperm. Chicken semen was diluted and incubated at $35^{\circ} \mathrm{C}$ in media supplemented with or without different doses of 5'-AMP-Activated Protein Kinase (AMPK) activator, Metf (0,5 to $5 \mathrm{mM})$. We then looked for the concentration improving the most sperm quality to use it in the cryopreservation media used for chicken sperm. Our results show that $1 \mathrm{mM}$ Metf is the concentration giving the best results regarding sperm quality. AMPK $\alpha$ phosphorylation, viability, acrosome reaction ability (AR), and various motility parameters, were negatively affected by the freeze-thaw process, and that Metf partially restored them. Sperm quality improved (mean increased by $23 \%$ for motility, by $10 \%$ for viability) as well as AMPK $\alpha$ phosphorylation (mean increased by $30 \%$ ). Moreover, fluorescent intensity levels of phosphoAMPK were also stronger with Metf than in the control. These results show that the presence of Metf in fresh semen has a positive impact on the quality of sperm and helps reducing the gradual decline in sperm motility caused by cryopreservation by partially restoring several essential sperm functions, and thus leads to a better overall quality of cryopreserved sperm.
\end{abstract}

Keywords: Acrosome reaction, chicken sperm, sperm motility, AMPK, Metformin

\section{INTRODUCTION}

Metformin (Metf) is a major actor in the treatment of type II diabetes, and is the only drug of the biguanide class currently used. It promotes insulin-stimulated glucose uptake in muscle (Bailey, 1993) and lowers hepatic glucose output (Hundal et al., 1992). It also affects lipid metabolism, lowering plasma triglycerides (Cusi et al., 1996), and free fatty acids (Abbasi et al., 1997), the latter possibly due to inhibition of catecholamine-stimulated lipolysis (Flechtner-Mors et al., 1999). In addition, it has also been shown that Metf can be used as an antineoplastic agent. Indeed, Metf restricts the growth and proliferation of various neoplastic cells both in vitro and in vivo. These results were described in different tumors, such as pulmonary adenocarcinoma (Wu et al., 2010), gastric (Kato et al., 2012), ovarian (Rattan et al., 2011; Yasmeen et al., 2011; Shank et al., 2012), prostate and colon cancer (Zakikhani et al., 2008), bladder neoplastic cells (Zhang et al., 2013) and different types of breast cancer (Zakikhani et al., 2006, 2010; Hirsch et al., 2009). Metf can also be used in the treatment of an ovulatory infertility in women (Palomba et al., 2006), inducing ovulation and increasing pregnancy rates (Lord et al., 2003; Creanga et al., 2008). However, if the effects of Metf on several organs have been broadly studied, little is known about its effects on the male germinal cells.

Cryopreservation is the most convenient technique for the long-term storage of sperm. It is a valuable technique used to conserve precious genetic material for domestic and endangered species and 
Nguyen Thi Mong Diep \& Elisabeth Blesbois

manage infertility in humans. However, despite the advancements made over the years, in most species, the post-thaw quality and function of sperm are impaired when compared with fresh sperm (Curry, 2000; Watson, 2000; Neild et al., 2005; John Morris et al., 2012). Cryopreservation causes permanent damage to sperm such as loss of motility, reduction of DNA integrity, damage to the acrosome and plasma membrane, and apoptosis (Curry, 2000; Watson, 2000; Neild et al., 2005; John Morris et al., 2012). This is why the extender composition and the nature of the external cryoprotectant compounds are of critical importance for sperm survival following cryopreservation (Bucak et al., 2013; Cordova et al., 2014). Various antioxidants have been added into the cryopreservation media and have improved sperm function such as motility and membrane integrity in numerous species (Branco et al., 2010; Garcez et al., 2010; Chhillar et al., 2012).

AMP-activated protein kinase (AMPK) is the downstream component of a protein kinase cascade that acts as a sensor of cellular energy charge. AMPK activation stimulates catabolic pathways that produce Adenosine triphosphate (ATP) and simultaneously inhibits ATPconsuming anabolic pathways, thus adjusting the cellular energy balance (Hardi, Hawley, 2001; Hardi et al., 2003, 2006). AMPK is a heterotrimeric protein consisting of a catalytic $\alpha$ subunit and two regulatory subunits, $\beta$ and $\gamma$, with different species and tissue-specific isoforms. AMPK is phosphorylated by upstream kinases, including Liver kinase B1 (LKB1 also known as serine/threonine kinase 11 (STK11)), $\mathrm{Ca} 2+/$ calmodulin-dependent protein kinase kinase (CaMKK) and transforming growth factor betaactivated kinase 1 (TAK1) (Woods et al., 2003; 2005; Momcilovic et al., 2006). AMPK is also activated by Metf (Zhou et al., 2001). Recently, it has been established that AMPK is present in sperm and that its activation affects the sperm quality in species such as boar, mouse, stallion, or chicken. Metf improves the quality of boar (Hurtado de Llera et al., 2012) and mouse frozenthawed sperm (Bertoldo et al., 2014) through AMPK activation. However, the role of Metf in chicken sperm has not been thoroughly studied. Based upon these interesting characteristics of Metf, this study evaluates its influence on sperm quality before and after cryopreservation by adding it directly into semen.

\section{MATERIALS AND METHODS}

\section{Animals}

The animals used were 28-55 week-old adult Gallus domesticus at the Institut National de la Recherche Agronomique (INRA) in France. All the animals were housed in individual battery cages under a $14 \mathrm{~L} / 10 \mathrm{D}$ photoperiod and fed a standard diet of $12.5 \mathrm{MJ} /$ day.

\section{Semen collection}

Semen was routinely collected twice a week by the abdominal massage method (Burrows, Quinn, 1937). Sperm samples were prepared as described by Blesbois et al. (2008). Fresh sperm samples were incubated in the presence or absence of different doses of Metf (Calbiochem) (0.5, 1, 2 and $5 \mathrm{mM}$ ). Stock solutions of Metf were prepared in deionized water. The most efficient concentrations affecting sperm parameters (viability, motility, and acrosome reaction) were chosen to perform the experiments on frozen sperm.

\section{Sperm cryopreservation and thawing procedures}

The semen was diluted 1:1 with Lake PC (Sigma-Aldrich) in the presence or absence of $1 \mathrm{mM}$ Metf and $11 \%$ glycerol based cryoprotectant in Lake PC (Lake, 1978). The semen was cryopreserved and thawed according to the method of Seigneurin and Blesbois (1995).

\section{Sperm viability}

SYBR-14/PI (LIVE/DEAD sperm viability kit; Molecular Probes) was used to assess sperm membrane integrity before freezing and after thawing. A total of 300 sperms per slide were counted (two slides $/$ sample $=1$ replicate) under fluorescence microscopy (Zeiss Axioplan 2; Zeiss Gruppe, Jena, Germany) and a total of six replicates/treatment examined. All preparations were analyzed by the same observer.

\section{Analysis of sperm motility by computer-assisted sperm analysis (CASA) system}

The sperm motility parameters were evaluated by the computer-assisted sperm analysis (CASA) system with an HTM-IVOS (Hamilton-Thorn Motility Analyzer, IVOS) (Blesbois et al., 2008). In this experiment, the parameters measured were percentage of motile sperm (\%), and rapid cells (percentage of motile sperm with VAP $>50 \mu \mathrm{m} / \mathrm{s}$, in $\%$ ). 
Acrosome reaction (AR) assessment with FITCPNA

The completion of the acrosome reaction was detected by FITC-conjugated peanut agglutinin (FITC-PNA) (Sigma-Aldrich) binding (Horrocks et al., 2000). The sperm having completed their acrosome reaction were identified and counted under fluorescence microscopy. A minimum of 100 sperm was counted for each sample (two slides/sample $=1$ replicate) and a total of six replicates/treatment examined. Acrosome reaction was characterized by the green fluorescence of the acrosomal region. All preparations were analyzed by the same observer.

\section{Western blotting}

For Western blotting experiments, total proteins from chicken sperm were extracted in lysis buffer. The protein concentration in each supernatant was determined by a colorimetric assay (Bio-Rad DC Protein Assay; Bio-Rad, Hercules, CA). The proteins were then separated by $10 \%$ SDS-PAGE (SDS Polyacrylamide Gel Electrophoresis) and transferred onto nitrocellulose membrane (Whatman Protran, Dassel, Germany). Afterwards, the membranes were incubated in anti-phospho-Thr172-AMPK $\alpha(63 \mathrm{kDa})$ (Millipore, Billerica, MA) or in anti-total AMPK $\alpha$ (63 kDa) (Millipore, Billerica, MA) (final dilution $1: 1000$ ) overnight at $4^{\circ} \mathrm{C}$. Finally, the membranes were further incubated for $1 \mathrm{~h}$ in (HRP)-conjugated secondary goat anti-rabbit antibody (Cell Signaling, Danvers, MA) (final dilution 1:2000). The intensity of bands in the signal was analyzed using Odyssey Software, version 1.2 (LICOR Biosciences, Lincoln, Nebraska, USA).

\section{Immunocytochemistry}

Total AMPK $\alpha$ and phospho-Thr172-AMPK $\alpha$ were localized in the chicken sperm by immunocytochemistry. Sperm cells were fixed in paraformaldehyde (Sigma-Aldrich) (4\%) for $4 \mathrm{~min}$, spread onto a Poly-L-lysine slide and then air-dried at room temperature. Sperm cells were washed in PBS (Sigma-Aldrich) and blocked with PBS supplemented with 10\% goat serum (Sigma-Aldrich) for $30 \mathrm{~min}$ at room temperature. The samples were then incubated overnight at $4^{\circ} \mathrm{C}$ with an antiAMPK $\alpha$ or an anti-phospho-Thr172-AMPK $\alpha$, diluted 1:50 in PBS-1\% goat serum, and then incubated with biotinylated goat anti-rabbit $\mathrm{IgG}$ $(\mathrm{H}+\mathrm{L})$ (Southern biotech, USA) $(1: 100$ in PBS-1\% goat serum) for $1 \mathrm{~h}$ at $4^{\circ} \mathrm{C}$. Then sperm cells were washed with PBS and incubated with Cy2Streptavidin (Southern biotech) (1:200 in PBS) for
$45 \mathrm{~min}$ at room temperature in the dark and incubated with 4',6'-diamidino-2-phenylindole (DAPI) (Sigma-Aldrich) $(0.05 \mu \mathrm{g} / \mathrm{mL})$ for $10 \mathrm{~min}$. The presence of total AMPK $\alpha$ and phospho-Thr172$\mathrm{AMPK} \alpha$ in sperm was examined by fluorescence microscopy. Negative control immunostaining was also performed at the same time by omitting the primary antibody.

\section{Statistical analyses}

Differences between treatments were analyzed by 1-way ANOVA and Bonferroni's multiple comparisons using GraphPad Prism version 5.0d for Macintosh computer (GraphPad Software, San Diego, CA). The minimum level of significance retained was $\mathrm{P}<0.05$.

\section{RESULTS}

\section{Metformin significantly increases the percentage of motile sperm}

To evaluate the effect of Metf on fresh sperm motility, sperm were incubated in BPSE in the presence or absence of Metf with different concentrations for $30 \mathrm{~min}$ at $35^{\circ} \mathrm{C}$. As observed in Figure 1, the percentage of sperm motility (Figure $1 \mathrm{~A})$ and rapid sperm (Figure $1 \mathrm{~B}$ ) is significantly reduced after $30 \mathrm{~min}$ of incubation compared with the negative control (Ctrl) which has not undergone incubation. However, after having treated the sperm with Metf, the sperm motility and rapid sperm parameters significantly increased (by about 41\%) with $1 \mathrm{mM}$ Metf, but did not change with other concentrations. Moreover, the percentage of rapid sperm tended to significantly decrease with increasing concentration of Metf ( $5 \mathrm{mM}$ Metf, $\mathrm{P}=$ 0.04) compared with other concentrations of Metf, but there was no difference compared to positive control (0 mM) (Figure 1B).

\section{Metformin significantly increases the percentage of sperm viability}

The effect of Metf in sperm viability was studied in order to correlate it with motility studies and to know whether Metf treatment might cause side effects that lead to germ cells death. According to the results shown in figure $2 \mathrm{~A}$, sperm viability was sensitive to time of incubation: after $30 \mathrm{~min}$, it significantly decreased compared with control which has not been incubated. However, in the presence of $1 \mathrm{mM}$ Metf, the decrease of sperm viability after 30 min of incubation was greatly limited; although other Metf doses did not produce a similar effect. 
Sperm motility (A)

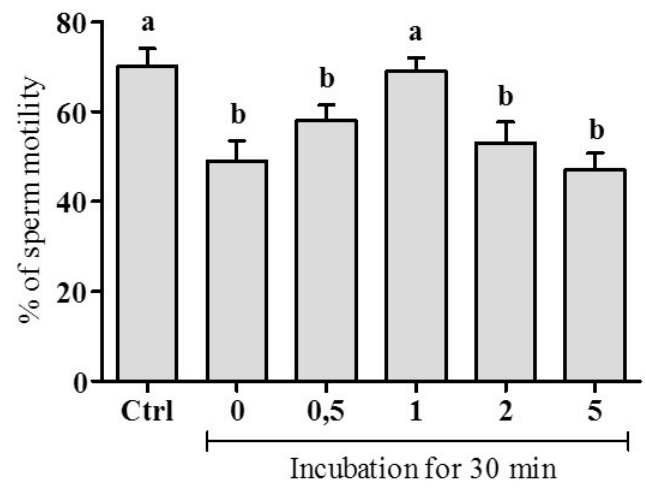

Rapid cell (B)

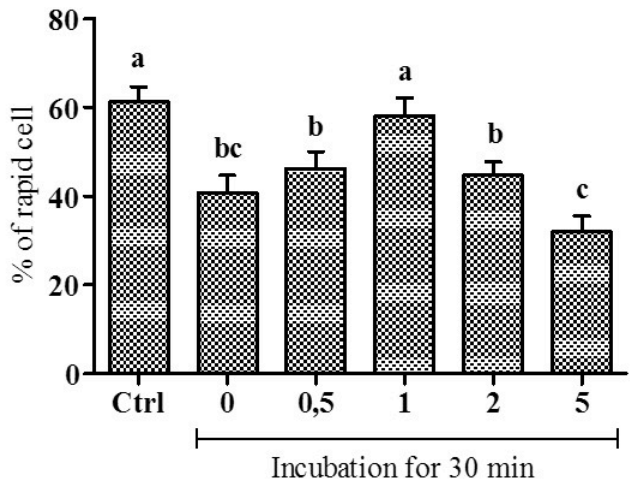

Figure 1. Effect of Metformin on sperm motility (A) and rapid sperm (B). Sperm were incubated in the presence of Metf at $0.5,1,2$, and $5 \mathrm{mM}$ for $30 \mathrm{~min}$. The positive control $(0 \mathrm{mM})$ comprised sperm incubated for $30 \mathrm{~min}$ in the absence of Metf. The negative control (Ctrl) comprised sperm that did not incubate for $30 \mathrm{~min}$. Values are means \pm SEM $(n=10)$. Different letters above bars indicate values that were statistically significantly different at $P<0.05$.

(A)

Sperm viability

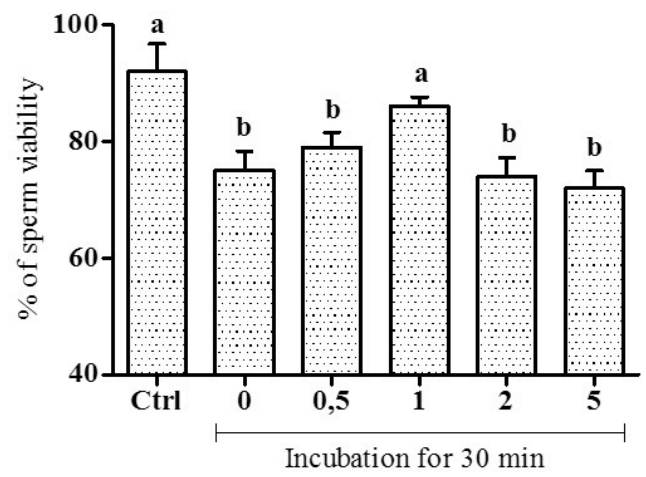

(B)

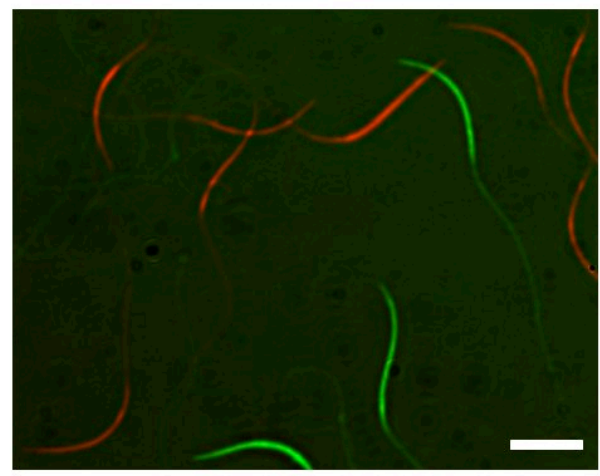

Figure 2. Effect of Metformin on sperm viability. (A) Sperm were incubated in the presence of Metf at $0.5,1,2$, and $5 \mathrm{mM}$ for $30 \mathrm{~min}$. The positive control $(0 \mathrm{mM})$ comprised sperm incubated for $30 \mathrm{~min}$ in the absence of Metf. The negative control (Ctrl) comprised sperm that did not incubate for $30 \mathrm{~min}$. Values are means \pm SEM $(n=10)$. Different letters above bars indicate values that were statistically significantly different at $P<0.05$. (B) Picture of sperm viability coloration with $S Y B R-$ 14/PI: the red fluorescence shows dead sperm and the green fluorescence shows live ones. Bars indicate $20 \mu \mathrm{M}$.

\section{Metformin significantly increases the percentage of sperm acrosome reaction}

The ability of spermatozoa to undergo the acrosome reaction was also negatively affected after $30 \mathrm{~min}$ of incubation compared to the negative control which has not been incubated $(\mathrm{P}<0.01)$. However, the acrosome reaction rate was significantly increased by Metf at $0.5 \mathrm{mM}$ (mean increase $\sim 22 \%$ ), at $1 \mathrm{mM}$ (mean increase $\sim 39 \%$ ) and at $2 \mathrm{mM}$ (mean increase $17 \%$ ) compared with the positive control $(0 \mathrm{mM})$, but not at $5 \mathrm{mM}$ Metf (Figure 3A). 
(A)

Acrosome reaction

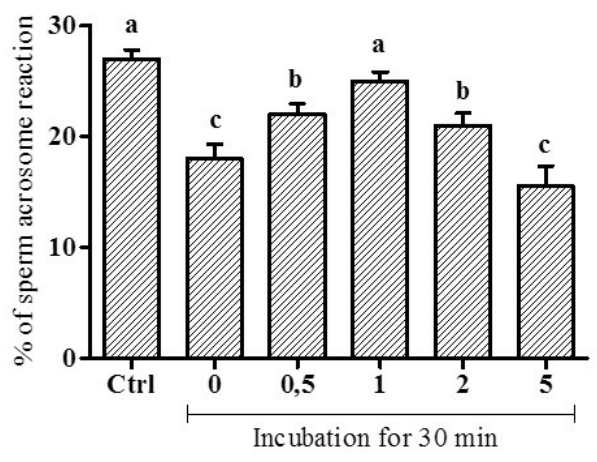

(B)

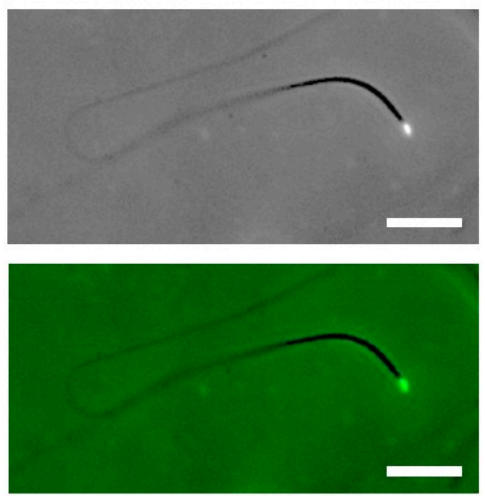

Figure 3. Effect of Metformin on sperm acrosome reaction. (A) Sperm were incubated in the presence of Metf at 0.5, 1, 2 , and $5 \mathrm{mM}$ for $30 \mathrm{~min}$. The positive control $(0 \mathrm{mM})$ comprised sperm incubated for $30 \mathrm{~min}$ in the absence of Metf. The negative control (Ctrl) comprised sperm that did not incubate for $30 \mathrm{~min}$. Values are means \pm SEM $(n=10)$. Different letters above bars indicate values that were statistically significantly different at $P<0.05$. (B) Picture of sperm acrosome reaction coloration with FICT-PNA: acrosome reaction is characterized by the green fluorescence of the acrosomal region. Bars indicate $20 \mu \mathrm{M}$.

\section{Effect of Metformin supplementation in cryopreservation media on spermatozoa}

Based on the results obtained from experiments with fresh sperm and according to the observation, 1 $\mathrm{mM}$ Metf is the most effective dose to improve chicken sperm quality. Therefore, the potential effect of $1 \mathrm{mM}$ Metf on cryopreserved sperm was tested.

Sperm parameters were assessed $15 \mathrm{~min}$ after

(A)

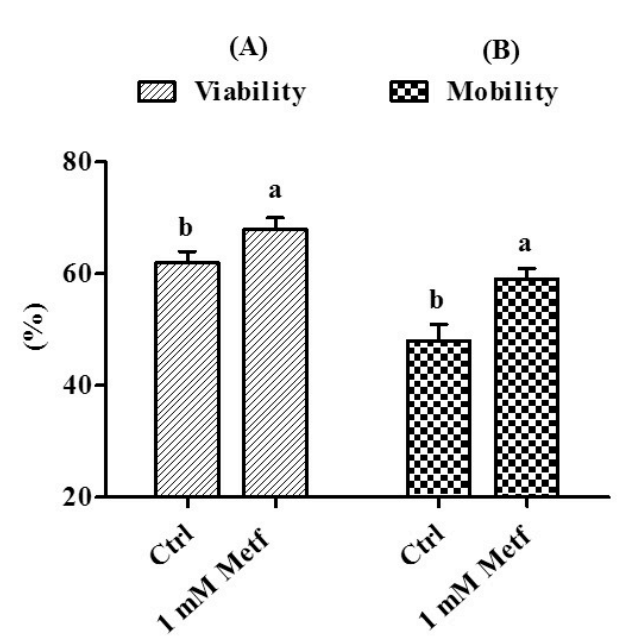

thawing. The results show that the sperm viability of the samples treated with Metf slightly increased (by 10\%) compared with control without Metf (Figure 4A). In addition, results obtained for motility were higher than those of the control without Metf. The percentage of motile sperm treated with Metf increased by $23 \%$ compared with control without Metf (Figure 4B). The decrease of sperm quality is also examined below by coloring cells with eosin-nigrosin in figure $4 \mathrm{C}$.

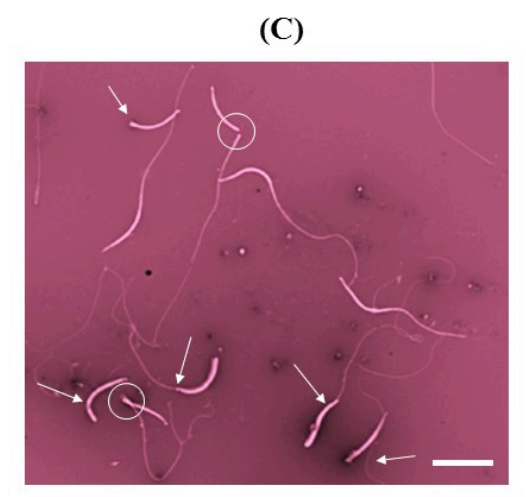

Figure 4. Effect of Metformin on frozen-thawed sperm viability (A) and motility (B). Sperm were incubated in the presence of $1 \mathrm{mM}$ Metf for 30 min before cryopreservation. The control (Ctrl) comprised sperm cryopreserved in the absence of Metf. Values are means \pm SEM $(n=6)$. Different letters above bars indicate values that were statistically significantly different at $P<$ 0.05. (C) Coloration with eosin-nigrosin shows that sperm morphology can be altered by deformations of the head or the flagella (highlighted by white arrows and circles), which can be either missing or misshapen. Bars indicate $10 \mu \mathrm{M}$. 
Phosphorylation of AMPK in frozen/thawed spermatozoa after Metformin treatment

Western blot analyses using antibodies against phospho-Thr172-AMPK $\alpha$ and total AMPK $\alpha$ (as Ctrl) were performed on chicken sperm incubated in the absence or presence of $1 \mathrm{mM}$ Metf during freezing and thawing (Figure 5). The AMPK phosphorylation was increased by $30 \%$ with Metf after the freezethaw process compared with control without Metf.

\section{Phospho-AMPKa ${ }^{\text {Thr172 }}$}

(63 kDa)

\section{Total AMPKa}

(63 kDa)
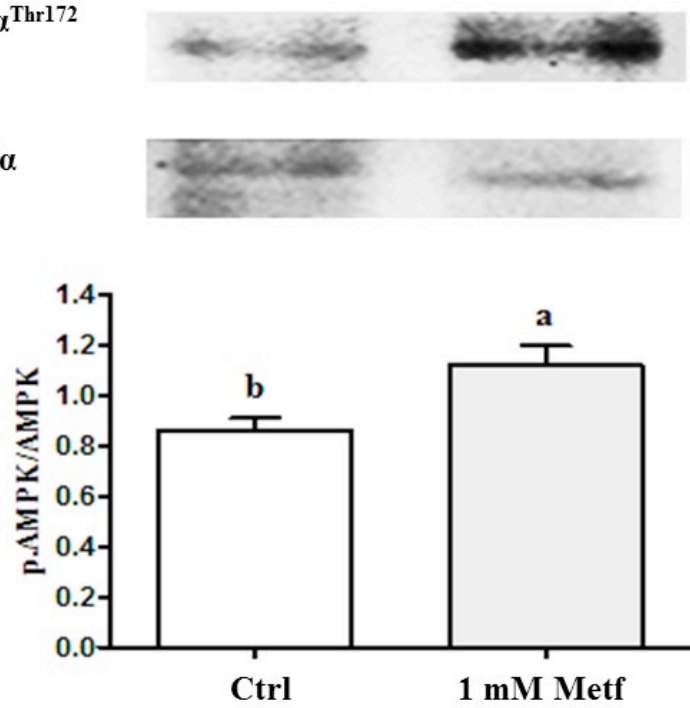

Figure 5. Metformin effects on AMPK phosphorylation in frozen-thawed chicken sperm. Sperm lysates were prepared and resolved by SDS-PAGE, transferred to nitrocellulose membrane, and probed with anti-phospho-Thr172-AMPKa and antiAMPKa antibody. Bands for phospho-Thr172-AMPKa were detected at $63 \mathrm{kDa}$ (top lanes). Total AMPKa was used as loading control $(63 \mathrm{kDa})$ (bottom lanes) and the phosphorylated protein AMPKa (Thr172)/total AMPKa ratio is shown at the bottom. Cryopreserved sperm were either treated in the presence of $1 \mathrm{mM}$ Metf (in dark gray) or without anything for the Ctrl (in white). Values represent means \pm SEM from 6 different experiments. Different superscripts indicate significant differences between $\mathrm{Ctrl}$ and Metf in frozen-thawed semen $(\mathrm{P}<0.05)$.

Negatif Ctrl

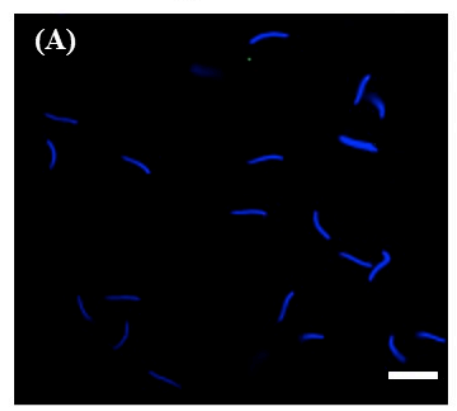

Positive Ctrl

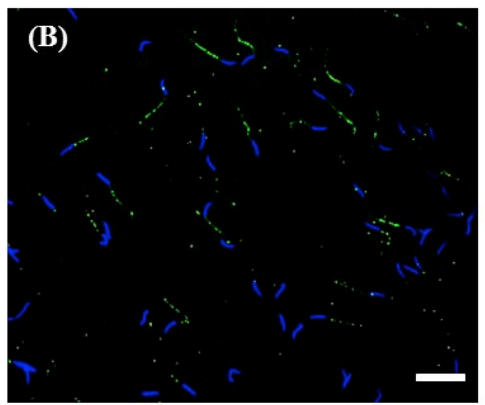

Metformin

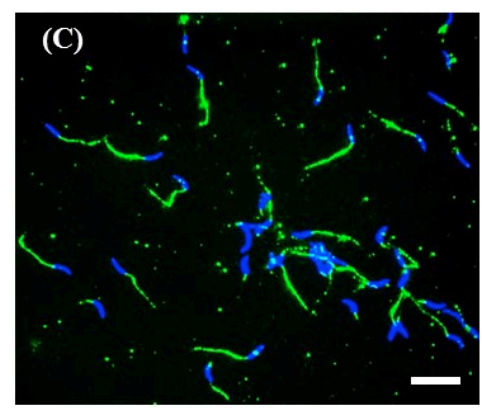

Figure 6. Metformin effects on the staining of phosphor-AMPK in chicken spermatozoa. Sperm cells were incubated with 1 $\mathrm{mM}$ Metf at $35^{\circ} \mathrm{C}$ for $30 \mathrm{~min}$ and then treated with antibodies to phospho-Thr172- AMPKa and with secondary antibody conjugated to biotin (see Materials and Methods). Immunofluorescence staining of phospho-Thr172-AMPK (green) was conducted in chicken spermatozoa. Nuclei were stained with DAPI (blue). Negative control (Negative Ctrl): primary antibody was not added (6A), positive control (Positive Ctrl): sperm incubated without Metf (6B), sperm incubated with Metf in figure 6C. Bars indicate $120 \mu \mathrm{M}$. 


\section{Metformin effects on the staining of phospho- AMPK in chicken spermatozoa}

We focused on the effects of Metf treatment on AMPK localization in spermatozoa at $30 \mathrm{~min}$. The staining of phospho-Thr172-AMPK protein was more visible in cells treated with Metf (Figure 6C) than in cells treated with vehicle alone as in control (Figure 6B). Specifically, in the Metf-treated cells, the staining of phospho-Thr172-AMPK in the flagellum was stronger than the one in the control.

\section{DISCUSSION}

There have been few reports assessing the effect of Metf on the viability of fresh or cryopreserved spermatozoa in vitro. This study figured that treatment of fresh or cryopreserved chicken spermatozoa with Metf presented a beneficial effect on motility, viability, and acrosome reaction. The results obtained with fresh spermatozoa in the present study differed from those of Hurtado de Llera et al. (2012), who observed a partial reduction in motility of boar spermatozoa following $5 \mathrm{mM}$ treatment with Metf in fresh spermatozoa for two h. Furthermore, they reported a complete inhibition with very high concentrations (between 10 and 20 mM) (Hurtado de Llera et al., 2012). Another study of Bertoldo et al. (2014) also showed that treatment of fresh mouse spermatozoa with $5 \mathrm{mM}$ Metf decreased sperm motility, but not sperm viability.

In this study, $1 \mathrm{mM}$ Metf treatment led to a significant increase in the percentage of viable, motile, and rapid spermatozoa (VAP > $50 \mu \mathrm{m} / \mathrm{s}$ ). However, Metf with a high concentration of $5 \mathrm{mM}$ did not affect sperm motility and viability but caused a significant reduction of the number of rapid spermatozoa. Moreover, the spermatozoa acrosome reaction was affected by Metf. The acrosome reaction occured by fusion of the sperm head cytoplasmic membrane and the underlying outer acrosomal membrane, so that the acrosome content was released (Okamura, Nishiyama, 1978). In most mammalian species, acrosome reaction occurs only in capacitated spermatozoa (Yanagimachi, 1994; Baldi et al., 2000), and capacitation requires specific environments and different substrates. But in chicken spermatozoa, the acrosome reaction can be induced very rapidly in vitro (Horrocks et al., 2000) without previous capacitation (Lemoine et al., 2008). Unlike in mice sperm (Bertoldo et al., 2014), there is no modification in acrosome reaction by Metf; this study indicated that Metf significantly increased chicken sperm acrosome reaction at $0.5,1$ and 2 $\mathrm{mM}$, but not $5 \mathrm{mM}$, which means that the effect of Metf is not the same in all animal species.

This study was also of the first showing a positive effect of Metf on the capacity of mature sperm to restore their biological functions after cryopreservation. Metf indeed improved sperm motility, acrosome reaction and viability in frozenthawed chicken sperm. These results differ from those obtained with stallion sperm, where Metf did not affect sperm viability and motility after cryopreservation (Cordova et al., 2014). However, in addition to the use of highly different doses of Metf in the two studies, the work on stallion sperm by Cordova et al. (2014) used a very specific hypometabolic medium of sperm storage, with restricted access to energetic substrate that greatly limits the potential comparisons with this study. In accordance with a previous study on epididymal mice sperm (Bertoldo et al., 2014), Metf showed a low but significant positive effect on sperm viability after cryopreservation.

In order to explain the positive action of Metf on fresh and frozen sperm functions, this study investigated the effects of Metf on AMPK phosphorylation. Recently, I showed the presence of the AMPK $\alpha$ protein in chicken sperm. AMPK presence in the acrosome, midpiece and flagellum of chicken spermatozoa is in relation to its possible function in spermatozoa motility and acrosome reaction process (Nguyen et al., 2014). In this study, an increased AMPK phosphorylation in frozen/thawed spermatozoa with $1 \mathrm{mM}$ Metf was measured. This indicated that the positive action of Metf on chicken sperm functions is done through AMPK activation. Metf was known as an indirect activator of AMPK which inhibits complex I of the mitochondrial respiratory chain, suggesting an AMPK activation through the increase of the AMP/ATP ratio (Owen et al., 2000). As presented, AMPK protein acts as a sensor that detects the cell energy state and subsequently regulates metabolism; when AMPK becomes activated it stimulates catabolic pathways that produce ATP and simultaneously inhibits ATP-consuming anabolic pathways. In this study, Metf was shown to allow phospho-Thr172- AMPK $\alpha$ in spermto be clearly seen through a strong stain. Therefore, the data strongly suggest that AMPK phosphorylation has a central role in regulating the improvement of metabolic 
functions and that ATP production is needed to ensure high energy consuming process such as spermatozoa motility and acrosome reaction.

However it is possible that Metfas a molecule of the biguanide family, and has the ability to decrease reactive oxygen species (Ouslimani et al., 2005; Piwkowska et al., 2010; Esteghamati et al., 2013) and to activate the transcription factor to increase expression of antioxidant genes (Onken, Driscoll, 2010). Sperm membranes are enriched in polyunsatured fatty acids (PUFAs) in mammalians (Dandekar et al., 2002) and bird species (Blesbois, Hermier, 2003), and sperms are very susceptible to lipid peroxidation (LPO) with subsequent alterations of structure and functions (Griveau et al., 1995). Superoxide dismutase (SOD), glutathione peroxidase (GPx), glutathione reductase (GR) and catalase (CAT) are the major antioxidant enzymes naturally present in mammalian and bird semen to protect sperm from lipid peroxidation and to maintain its integrity against ROS (Surai et al., 1998). Reductions in SOD, GPx, catalase activities, and increases in ROS and LPO have been shown after chicken sperm cryopreservation (Partyka et al., 2012). Previous studies have provided evidence that Metf exerts an anti-inflammatory effect on nonalcoholic steato-hepatosis mice by preventing depletion in GPx, SOD, and catalase, and by decreasing ROS and MDA (Buldak et al., 2014). Metf could also directly reduce ROS production via inhibition of complex I. Indeed, the inhibition of complex I by Metf is known to reduce the number of electrons entering the electron transport chain, thus blocking NADH oxidation by complex I (Piwkowska et al., 2010), and therefore reducing ROS production by both complex I and III (Ouslimani et al., 2005). It suggests that the impact of Metf on sperm quality is made through both AMPK-dependent and AMPK-independent pathways (Kita et al., 2012).

\section{CONCLUSIONS}

The results in this study demonstrated that Metf increased the quality of fresh chicken spermatozoa. Furthermore, chicken sperm cryopreserved in the presence of Metf have improved post-thaw motility and viability. This is the first assessment of the effect of Metf on chicken sperm through their influence on AMPK activity to reduce cryopreservation damages in avian sperm. Such data will most certainly be helpful to develop and improve semen handling and storage techniques in the near future.

Acknowledgements: This study was performed with the financial support of the French Agence Nationale de la Recherche (http://www.agence-nationalerecherche.fr/), INRA (http://www.inra.fr). Special thanks would be sent to Isabelle Grasseau, Sabine Alves (INRA) for help regarding the methodology and the staff of the INRA experimental unit PEAT for the animal breeding and participation in semen collections.

\section{REFERENCES}

Abbasi F, Kamath V, Rizvi AA, Carantoni M, Chen YD, Reaven GM (1997) Results of a placebo-controlled study of the metabolic effects of the addition of Metformin to sulfonylurea-treated patients. Evidence for a central role of adipose tissue. Diabetes Care 20: 1863-1869.

Bailey CJ (1993) Metformin - an update. General Pharmacology 24: 1299-1309.

Baldi E, Luconi M, Bonaccorsi L, Muratori M, Forti G (2000) Intracellular events and signaling pathways involved in sperm acquisition of fertilizing capacity and acrosome reaction. Frontiers in Bioscience 5: 110-123.

Bertoldo MJ, Guibert E, Tartarin P, Guillory V, Froment P (2014) Effect of Metf on the fertilizing ability of mouse spermatozoa. Cryobiology 68: 262-268.

Blesbois E, Grasseau I, Seigneurin F, Mignon-Grasteau S, Saint Jalme M, Mialon-RichardmM (2008) Predictors of success of semen cryopreservation in chickens. Theriogenology 69: 252-261.

Blesbois E, Hermier D (2003) Specificity of fatty acids in domestic birds spermatozoa. In: Vriese, D. (Eds). Male Fertility and Lipid Metabolism. Champaign IL. American Oil Chemist's Society Press pp: 73-85.

Branco CS, Garcez ME, Pasqualotto FF, Erdtman B, Salvador M (2010) Resveratrol and ascorbic acid prevent DNA damage induced by cryopreservation in human semen. Cryobiology 60: 235-237.

Bucak MN, Keskin N, Taspinar M, Coyan K, Baspinar N, Cenariu MC, Bilgili A, Ozturk C, Kursunlu AN (2013) Raffinose and hypotaurine improve the post-thawed Merino ram sperm parameters. Cryobiology 67: 34-39.

Buldak L, Labuzek K, Buldak RJ, Kozlowski M, Machnik G, Liber S, Suchy D, Dulawa-Buldak A, Okopien B (2014) Metformin affects macrophages' phenotype and improves the activity of glutathione peroxidase, superoxide dismutase, catalase and decreases malondialdehyde concentration in a partially AMPK-independent manner in 
LPS-stimulated human monocytes/macrophages. Pharmacol Rep 66: 418-429.

Burrows WH, Quinn JP (1937) The collection of spermatozoa from the domestic fowl and turkey. Poultry Science 16: 19-24.

Creanga AA, Bradley HM, McCormick C, Witkop CT (2008) Use of Metf in polycystic ovary syndrome: a metaanalysis. Obstet Gynecol 111: 959-968.

Chhillar S, Singh VK, Kumar R, Atreja SK (2012) Effects of Taurine or Trehalose supplementation on functional competence of cryopreserved Karan Fries semen. Anim Reprod Sci 135: 1-7.

Cordova A, Strobel P, Vallejo A, Valenzuela P, Ulloa O, Burgos RA, Menarim B, Rodriguez-Gil JE, Ratto M, Ramirez-Reveco A (2014) Use of hypometabolic TRIS extenders and high cooling rate refrigeration for cryopreservation of stallion sperm: presence and sensitivity of $5^{\prime}$ AMP-activated protein kinase (AMPK). Cryobiology 69: 473-481.

Curry MR (2000) Cryopreservation of semen from domestic livestock. Reviews of reproduction 5: 46-52.

Cusi K, Consoli A, DeFronzo RA (1996) Metabolic effects of metformin on glucose and lactate metabolism in noninsulin-dependent diabetes mellitus. J Clin Endocrinol Metab 81: 4059-4067.

Dandekar SP, Nadkarni GD, Kulkarni VS, Punekar S (2002) Lipid peroxidation and antioxidant enzymes in male infertility. J Postgrad Med 48: 186-190.

Esteghamati A, Eskandari D, Mirmiranpour H, Noshad S, Mousavizadeh M, Hedayati M, Nakhjavani M (2013) Effects of metformin on markers of oxidative stress and antioxidant reserve in patients with newly diagnosed type 2 diabetes: a randomized clinical trial. Clin Nutr 32: 179185 .

Flechtner-Mors M, Ditschuneit HH, Jenkinson CP, Alt A, Adler G (1999) Metformin inhibits catecholaminestimulated lipolysis in obese, hyperinsulinemic, hypertensive subjects in subcutaneous adipose tissue: an in situ microdialysis study. Diabet Med 16: 1000-1006.

Garcez ME, dos Santos Branco C, Lara LV, Pasqualotto FF, Salvador M (2010) Effects of resveratrol supplementation on cryopreservation medium of human semen. Fertil Steril 94: 2118-2121.

Griveau JF, Dumont E, Renard P, Callegari JP, Le Lannou D (1995) Reactive oxygen species, lipid peroxidation and enzymatic defence systems in human spermatozoa. $J$ Reprod Fertil 103: 17-26.

Hardie DG, Hawley SA (2001) AMP-activated protein kinase: the energy charge hypothesis revisited. Bioessays 23: $1112-1119$.
Hardie DG, Hawley SA, Scott JW (2006) AMP-activated protein kinase-development of the energy sensor concept. J Physiol 574: 7-15.

Hardie DG, Scott JW, Pan DA, Hudson ER (2003) Management of cellular energy by the AMP-activated protein kinase system. FEBS Lett 546: 113-120.

Hirsch HA, Iliopoulos D, Tsichlis PN, Struhl K (2009) Metformin selectively targets cancer stem cells, and acts together with chemotherapy to block tumor growth and prolong remission. Cancer Res 69: 7507-7511.

Horrocks AJ, Stewart S, Jackson L, Wishart GJ (2000) Induction of acrosomal exocytosis in chicken spermatozoa by inner perivitelline-derived N-linked glycans. Biochem Biophys Res Commun 278: 84-89.

Hundal HS, Ramlal T, Reyes R, Leiter LA, Klip A (1992) Cellular mechanism of metformin action involves glucose transporter translocation from an intracellular pool to the plasma membrane in L6 muscle cells. Endocrinology 131: 1165-1173.

Hurtado de Llera A, Martin-Hidalgo D, Gil MC, GarciaMarin LJ, Bragado MJ (2012) AMP-activated kinase AMPK is expressed in boar spermatozoa and regulates motility. PLoS One 7: e38840.

Kato K, Gong J, Iwama H, Kitanaka A, Tani J, Miyoshi H, Nomura K, Mimura S, Kobayashi M, Aritomo Y, Kobara H, Mori H, Himoto T, Okano K, Suzuki Y, Murao K, Masaki T (2012) The antidiabetic drug metformin inhibits gastric cancer cell proliferation in vitro and in vivo. Mol Cancer Ther 11: 549-560.

Kita Y, Takamura T, Misu H, Ota T, Kurita S, Takeshita $\mathrm{Y}$, Uno $\mathrm{M}$, Matsuzawa-Nagata $\mathrm{N}$, Kato $\mathrm{K}$, Ando $\mathrm{H}$, Fujimura A, Hayashi K, Kimura T, Ni Y, Otoda T, Miyamoto K, Zen Y, Nakanuma Y, Kaneko S (2012) Metformin prevents and reverses inflammation in a nondiabetic mouse model of nonalcoholic steatohepatitis. PLoS One 7: e43056.

Lake PE, Stewart JM (1978) Preservation of fowl semen in liquid nitrogen--an improved method. Br Poult Sci 19: 187-194.

Lemoine M, Grasseau I, Brillard JP, Blesbois E (2008) A reappraisal of the factors involved in in vitro initiation of the acrosome reaction in chicken spermatozoa. Reproduction 136: 391-399.

Lord JM, Flight IH, Norman RJ (2003) Metformin in polycystic ovary syndrome: systematic review and metaanalysis. $B M J$ 327: 951-953.

Momcilovic M, Hong SP, Carlson M (2006) Mammalian TAK1 activates Snf1 protein kinase in yeast and phosphorylates AMP-activated protein kinase in vitro. $J$ Biol Chem 281: 25336-25343. 
John Morris G, Acton E, Murray BJ, Fonseca F (2012) Freezing injury: the special case of the sperm cell. Cryobiology 64: 71-80.

Neild DM, Brouwers JF, Colenbrander B, Aguero A, Gadella BM (2005) Lipid peroxide formation in relation to membrane stability of fresh and frozen thawed stallion spermatozoa. Mol Reprod Dev 72: 230-238.

Nguyen TMD, Alves S, Grasseau I, Metayer-Coustard S, Praud C, Froment P, Blesbois E (2014) Central role of 5'AMP-activated protein kinase in chicken sperm functions. Biol Reprod 91: 1-15.

Okamura F, Nishiyama H (1978) The passage of spermatozoa through the vitelline membrane in the domestic fowl, Gallus gallus. Cell Tissue Res 188: $497-$ 508 .

Onken B, Driscoll M (2010) Metformin induces a dietary restriction-like state and the oxidative stress response to extend C. elegans Healthspan via AMPK, LKB1, and SKN-1. PLoS One 5: e8758.

Ouslimani N, Peynet J, Bonnefont-Rousselot D, Therond P, Legrand A, Beaudeux JL (2005) Metformin decreases intracellular production of reactive oxygen species in aortic endothelial cells. Metabolism 54: 829-834.

Owen MR, Doran E, Halestrap AP (2000) Evidence that Metformin exerts its anti-diabetic effects through inhibition of complex 1 of the mitochondrial respiratory chain. Biochem J 348: 607-614.

Palomba S, Orio F, Jr., Falbo A, Russo T, Tolino A, Zullo F (2006) Effects of metformin and clomiphene citrate on ovarian vascularity in patients with polycystic ovary syndrome. Fertil Steril 86: 1694-1701.

Partyka A, Lukaszewicz E, Nizanski W (2012) Effect of cryopreservation on sperm parameters, lipid peroxidation and antioxidant enzymes activity in fowl semen. Theriogenology 77: 1497-1504.

Piwkowska A, Rogacka D, Jankowski M, Dominiczak MH, Stepinski JK, Angielski S (2010) Metformin induces suppression of $\mathrm{NAD}(\mathrm{P}) \mathrm{H}$ oxidase activity in podocytes. Biochem Biophys Res Commun 393: 268-273.

Rattan R, Giri S, Hartmann LC, Shridhar V (2011) Metformin attenuates ovarian cancer cell growth in an AMP-kinase dispensable manner. J Cell Mol Med 15: 166178.

Seigneurin F, Blesbois E (1995) Effects of freezing rate on viability and fertility of frozen-thawed fowl spermatozoa. Theriogenology 43: 1351-1358.

Shank JJ, Yang K, Ghannam J, Cabrera L, Johnston CJ, Reynolds RK, Buckanovich RJ (2012) Metformin targets ovarian cancer stem cells in vitro and in vivo. Gynecol Oncol 127: 390-397.
Surai PF, Blesbois E, Grasseau I, Chalah T, Brillard JP, Wishart GJ, Cerolini S, Sparks NH (1998) Fatty acid composition, glutathione peroxidase and superoxide dismutase activity and total antioxidant activity of avian semen. Comp Biochem Physiol B Biochem Mol Biol 120: 527-533.

Watson PF (2000) The causes of reduced fertility with cryopreserved semen. Anim Reprod Sci 60-61: 481-492.

Woods A, Johnstone SR., Dickerson K, Leiper FC, Fryer LG, Neumann D, Schlattner U Wallimann T, Carlson M, Carling D (2003) LKB1 is the upstream kinase in the AMP-activated protein kinase cascade. Current biology 13: 2004-2008.

Woods A, Dickerson K, Heath R, Hong SP, Momcilovic M, Johnstone SR, Carlson M, Carling D (2005) $\mathrm{Ca} 2+/$ calmodulin-dependent protein kinase kinase-beta acts upstream of AMP-activated protein kinase in mammalian cells. Cell Metab 2: 21-33.

Wu N, Gu HJ, Li Q (2010) Effects of antidiabetic drug metformin on the migration and invasion abilities of human pulmonary adenocarcinoma A549 cell line in vitro. $J$ Thorac Dis 2: 76-80.

Yanagimachi R (1994) Fertility of mammalian spermatozoa: its development and relativity. Zygote 2: 371-372.

Yasmeen A, Beauchamp MC, Piura E, Segal E, Pollak M, Gotlieb WH (2011) Induction of apoptosis by metformin in epithelial ovarian cancer: involvement of the Bcl-2 family proteins. Gynecol Oncol 121: 492-498.

Zakikhani M, Blouin MJ, Piura E, Pollak MN (2010) Metformin and rapamycin have distinct effects on the AKT pathway and proliferation in breast cancer cells. Breast Cancer Res Treat 123: 271-279.

Zakikhani M, Dowling R, Fantus IG, Sonenberg N, Pollak M (2006) Metformin is an AMP kinase-dependent growth inhibitor for breast cancer cells. Cancer Res 66: 1026910273.

Zakikhani M, Dowling RJ, Sonenberg N, Pollak MN (2008) The effects of adiponectin and metformin on prostate and colon neoplasia involve activation of AMPactivated protein kinase. Cancer Prev Res (Phila) 1: 369375 .

Zhang T, Guo P, Zhang Y, Xiong H, Yu X, Xu S, Wang $X$, He D, Jin $X$ (2013) The antidiabetic drug metformin inhibits the proliferation of bladder cancer cells in vitro and in vivo. Int J Mol Sci 14: 24603-24618.

Zhou G, Myers R, Li Y, Chen Y, Shen X, Fenyk-Melody J, Wu M, Ventre J, Doebber T, Fujii N, Musi N, Hirshman MF, Goodyear LJ, Moller DE (2001) Role of AMPactivated protein kinase in mechanism of metformin action. J Clin Invest 108: 1167-1174. 


\title{
ẢNH HƯởNG CỦA CHẤT KÍCH HOẠT AMPK METFORMIN ĐẾN CHẤT LƯợNG TINH TRÙNG
}

\author{
Nguyen Thi Mong Diep ${ }^{1}$, Elisabeth Blesbois ${ }^{2}$ \\ ${ }^{1}$ Trưòng Đại học Quy Nhơn, Việt Nam \\ ${ }^{2}$ Viện Nông nghiệp Quốc gia, Sinh lý học sinh sản và tập tính, 37380 Nouzilly, Pháp
}

\section{TÓM TẮT}

Bảo quản lạnh tinh dịch cho phép quản lý sự đa dạng di truyền động vật. Tuy nhiên, quá trình đông lạnh giải đông đã làm thay đổi hình dạng, đặc tính sinh hóa, nguồn năng lượng... dẫn đến suy giảm chất lượng tinh trùng. Hiện nay, nhiều thành phần được thêm vào môi trường đông lạnh để nâng cao chất lượng tinh trùng đông lạnh - giải đông trong quá trình thụ tinh nhân tạo. Mục tiêu của nghiên cứu này là xác định tác động của Metformin (Metf) đển khả năng di chuyển của tinh trùng gà và khả năng thực hiện phản ứng acrosome, đồng thời đánh giá tác động của Metf đến các chức năng của tinh trùng bảo quản lạnh. Tinh dịch gà đã được pha loãng và ủ ở $35^{\circ} \mathrm{C}$ trong môi trường có hoặc không bổ sung chất kích hoạt $\mathrm{AMPK}$, Metf ở các nồng độ khác nhau (từ 0,5 đến $5 \mathrm{mM}$ ) và nồng độ cải thiện chất lượng tinh trùng tốt nhất sẽ được bổ sung vào môi trường bảo quản lạnh tinh trùng gà. Kết quả cho thấy $1 \mathrm{mM}$ Metf là nồng độ cho kết quả tốt nhất về chất lượng tinh trùng. Phosphoryl hóa $\mathrm{AMPK} \alpha$, khả năng sống, khả năng phản ứng acrosome (AR) các thông số di động đều bị ảnh hưởng tiêu cực bởi quá trình đông lạnh - giải đông và Metf đã phục hồi một phần tiêu cực đó. Chất lượng tinh trùng được cải thiện (trung bình tăng $23 \%$ đối với di động, $10 \%$ đối với khả năng sống) cũng như phosphoryl hóa AMPKa (trung bình tăng 30\%). Hơn nữa, cường độ huỳnh quang của phospho-AMPK cũng mạnh hơn với Metf so với trong đối chứng. Các kết quả này cho thấy sự có mặt của Metf trong tinh dịch tươi có tác động tích cực đến chất lượng tinh trùng và giúp hạn chế sự giảm dần khả năng di chuyển tinh trùng do việc bảo quản lạnh và bằng cách phục hồi các chức năng của tinh trùng đã dẫn đến chất lượng tinh trùng đông lạnh được bảo quản tốt hơn.

Tù̀ khóa: Phản úng Acrosome, tinh trùng gà, chuyển động của tinh trùng, AMPK, Metformin 